Aby więc mówić o ofierze i kapłaństwie Chrystusa, będę się odwoływał przede wszystkim do tego listu. Jego autor okazuje się doskonałym znawcą Starego Testamentu, ale równocześnie bardzo dobrze zdaje sobie sprawę z nowości chrześcijaństwa. Często nawet współcześni chrześcijanie mniej uświadamiają sobie tę nowość i pozostają bardziej przywiązani do starotestamentalnego ujmowania ofiary i kapłaństwa, nie zdając sobie nawet $\mathrm{z}$ tego sprawy. Pogłębienie tego zagadnienia wydaje się więc niezbędne, aby je ustawić we właściwym świetle. Zobaczymy też, jak ważne jest powiązanie tych duchowych rzeczywistości z Sercem Chrystusa.

\section{KAPŁAŃSTWO CHRYSTUSA}

Nie tak łatwo wyrobić sobie dokładne pojęcie na temat kapłaństwa Chrystusowego. Trudność bierze się przede wszystkim stąd, że chodzi o tajemnicę zawierającą wiele aspektów, jak również i z faktu, że jesteśmy zawsze bardziej skłonni stosować do kapłaństwa Chrystusowego starotestamentalne pojęcie kapłaństwa. Przez to tracimy z pola widzenia jego zasadniczą oryginalność.

\section{Różnica między Chrystusem a kapłaństwem starotestamentalnym}

Starotestamentalne pojęcie kapłaństwa nie jest właściwe dla zdefiniowania kapłaństwa Chrystusowego, które jest kapłaństwem nowym, ponieważ Chrystusa jest „pośrednikiem nowego przymierza” (Hbr 9,15; 12,24; por. 7,22; $8,6)$.

Różnice między misterium Chrystusa a instytucją kapłaństwa starotestamentalnego są tak wielkie i głębokie, że najwcześniejszy kerygmat chrześcijański w ogóle nie mówił o kapłaństwie w odniesieniu do Chrystusa, ani też nie używał pojęcia ofiary w odniesieniu do jego śmierci. Rzeczywiście, według kategorii starotestamentalnych, Jezus w ogóle nie był kapłanem ani nawet nie mógł nim zostać, ponieważ nie pochodził $\mathrm{z}$ rodu Aarona ani pokolenia Lewiego. Zaś przynależność do potomstwa Aarona była nieodzownym warunkiem do tego, aby w ogóle można było sprawować funkcje kapłańskie. Stary Testament nie dopuszcza żadnych wyjątków w tym względzie. W Lb 3,10 Bóg nakazuje Mojżeszowi: „Aaronowi i jego synom zlecisz, by pełnili powierzoną im służbę kapłańską. Gdyby się zbliżył (do ołtarza) ktoś niepowołany, ma być ukarany śmiercią". Podobny przepis dotyczy uprawnień lewitów: jedynie oni winni sprawować pieczę nad Przybytkiem. „Jeśli zbliży się do Przybytku ktoś niepowołany, będzie ukarany śmiercią" (Lb 1,51).

Będąc potomkiem Dawida i należąc do pokolenia Judy, nie mógł Jezus wchodzić do Przybytku świątyni ani sprawować jakiejkolwiek funkcji kapłańskiej. Był tego w pełni świadomy i nigdy nie okazywał żadnych pretensji w tym względzie. Jego działalność publiczna nie była kapłańską w starotestamentalnym sensie tego słowa. Była to raczej działalność prorocka i nauczycielska. Podobnie jak prorocy głosił Jezus słowo Boże i zapowiadał zbliżającą się interwencję Boga: „bliskie jest królestwo Boże. Nawracajcie się i wierzcie w Ewan- 
gelię" (Mk 1,15). Podobnie jak prorocy posługiwał się niekiedy czynnościami symbolicznymi (np. znak uschłego drzewa figowego w Mt 21,18-22) i dokonywał cudownych znaków, podobnie jak prorocy Eliasz i Elizeusz. Na widok takich znaków ludzie wykrzykiwali z radością: „Wielki prorok powstał wśród nas i Bóg łaskawie nawiedził lud swój!” $(Ł k 7,16)$.

Częstszą działalnością Jezusa było jednak nauczanie. Był On uważany powszechnie za „rabbiego”, czyli nauczyciela. Zwracając się do Niego używali ludzie najczęściej tego tytułu, czy to w formie hebrajskiej lub aramejskiej rabbi (np. Piotr w czasie przemienienia na górze Tabor - Mk 9,5; Nikodem w J 3,2 itd.), czy też częściej, w greckim brzmieniu didaskale (Mt 8,19; 12,38...). Ewangeliści jednak zauważają, że Jego sposób nauczania był oryginalny, „nowy” (Mk 1,27). „Uczył ich bowiem jak ten, który ma władzę, a nie jak uczeni w Piśmie" (Mk 1,22; Mt 4,29).

Jeden aspekt tego nauczania interesuje nas w sposób szczególny, ponieważ dotyczy sposobu pojmowania kultu i praktykowania go. Ewangelie zaświadczają o tym, że Jezus prowadził systematyczną akcję przeciw rytualistycznemu pojmowaniu relacji z Bogiem. Nie wahał się postawić uzdrawiania chorych przed zachowywaniem szabatu i stanowczo odmawiał religijnej wartości regułom czystości zewnętrznej. Walczył z formalizmem i wymagał prawdziwego posłuszeństwa Bogu w konkretnym życiu. W tym sensie Jezus umieścił się w nurcie tradycji prorockiej. Wiadomo, że prorocy izraelscy często dystansowali się od kapłaństwa. W wielu wyroczniach gwałtownie krytykowali kult rytualny, wyrażali niezadowolenie Boga z ofiar zwierzęcych: „Co mi po mnóstwie waszych ofiar? - mówi Pan. Syt jestem całopaleń... Krew wolów i kozłów mi obrzydła” (Iz 1,11). „Niech raczej sprawiedliwość wystąpi jak woda z brzegów i prawość jak potok niewysychający wyleje! (Am 5,24). Egzegeci wyjaśniają, że proroctwa te były rozumiane w sposób względny: prorocy przecież nie mogli całkowicie odrzucić kultu rytualnego, jako że był on przepisany przez Prawo Mojżeszowe i uważany za wyraz woli Bożej. Przeciwstawiali się temu kultowi, o ile był sprawowany bez koniecznych dyspozycji ducha. Ich sformułowania jednak przygotowywały, mimo iż sobie $z$ tego sami nie zdawali sprawy, przemianę zasadniczą.

Jezus właśnie dokonał tej przemiany. W Ewangelii Mateusza podejmuje On dwa razy slowo Boże oznajmione przez proroka Ozeasza: „Chcę raczej milosierdzia niż ofiary" (Oz 6,6; Mt 9,13; 12,7). Są to jedyne dwa teksty, w których greckie słowo thysia, oznaczające ofiary rytualne, znajduje się na ustach Jezusa. Obydwa razy Jezus używa tego słowa aby oznajmić, że Bóg nie chce tego rodzaju ofiar. Przez tę dwukrotną deklarację Jezus dystansował się od starotestamentalnego kultu kapłańskiego, którego kulminacyjnym aktem były ofiary rytualne i obpowiadał się za innym sposobem oddawania czci Bogu poprzez praktykowanie miłosierdzia w stosunku do innych ludzi. Kultowi rytualnemu przeciwstawiał kult egzystencjalny.

Tę orientację utrzymał Jezus aż do śmierci. Przyzwyczailiśmy się traktować śmierć Jezusa jako ofiarę. Nie zdajemy sobie jednak sprawy, że z punktu widzenia kapłaństwa starotestamentalnego śmierć Jezusa nie była ofiarą ani nawet nią być nie mogła. Wprost przeciwnie, była ona zaprzeczeniem ofiary. 
Według pojęć Starego Testamentu ofiara nie polegała na zabiciu zwierzęcia ofiarnego ani na zadawaniu mu cierpień, lecz na rytach ofiarniczych dokonywanych przez kapłana w miejscu świętym. Zaś śmierć Jezusa nie nastąpiła w miejscu świętym, ale na zewnątrz Miasta Świętego i nie towarzyszyły jej żadne ryty liturgiczne. Jego śmierć nie mogła być ofiarą, ponieważ zamiast być konsekracją była wyklęciem, czyli czymś całkowicie przeciwnym. Śmierć Jezusa była wykonaniem kary przewidzianej przez Prawo. Żydzi zaś widzieli całkowite przeciwieństwo między śmiercią skazanego a ofiarą rytualną. Obrzędy rytualne przekształcały złożenie ofiary w akt bardzo uroczysty, chwalebny, który niejako podnosił ofiarę do Boga i wyjednywał błogosławieństwo Boże. Smierć skazańca była zaś traktowana nie tylko jako najgorsza z kar, ale jako kara zniesławiająca, która zamiast łączyć z Bogiem i wyjednywać błogosławieństwo, sama była przekleństwem (Pwt 21,23). Sw. Paweł nie waha się stwierdzić, że Chrystus „za nas stał się przekleństwem, bo napisane jest: Przeklęty każdy, którego powieszono na drzewie" (Ga 3,13). Według mentalności starotestamentalnej więc śmierć Jezusa na Kalwarii odłączała Go bezpowrotnie od kultu i kapłaństwa. Dlatego jest całkowicie zrozumiałe, że najwcześniejsze nauczanie chrześcijańskie nie mówiło ani o ofierze ani o kapłaństwie w odniesieniu do Chrystusa. Czytajcie uważnie kazania przytoczone w Dziejach Apostolskich, a nie znajdziecie w nich nawet najmniejszej aluzji do kapłaństwa Jezusa. To co tam widać, to przede wszystkim egzystencjalny aspekt tajemnicy Chrystusa, Jego śmierci jako skazańca i Jego zmartwychwstania. Musimy dobrze pamiętać o tych podstawowych faktach, jeżeli chcemy wyrobić sobie właściwe pojęcie na temat kapłaństwa Chrystusowego, a co za tym idzie, również i naszego kapłaństwa.

Zastosowanie do tajemnicy Chrystusa pojęcia ofiary i kapłaństwa nie było możliwe bez głębokiego przepracowania tych pojęć, które pozwoliłoby ukazać całą jej nowość i oryginalność.

\section{Pojęcie kapłaństwa starotestamentalnego}

Starotestamentalne pojęcie kapłaństwa było rytualne i opierało się na szukaniu uświęcenia za pomocą oddzieleń rytualnych. Jego celem było osiągnięcie dobrej relacji z Bogiem, ponieważ ludzie byli przekonani o zasadniczym jej znaczeniu dla człowieka. Błogosławieństwo Boże było potrzebne, aby się człowiekowi dobrze powodziło w życiu, aby udawały się przedsięwzięcia, aby mieć dobre układy z innymi, dobre zdrowie, liczne potomstwo, obfite zbiory, aby osiągnąc zwycięstwo na wojnie. Hebrajczycy jednak odczuwali całą tę wielką odległość, która oddzielała ich od Boga, ponieważ człowiek jest istotą ziemską, podczas gdy Bóg jest samą świętością, ogniem spalającym. Spotkanie z Bogiem uważano więc za coś bardzo niebezpiecznego. Nie można widzieć Boga i pozostać przy życiu (Wj 33,20).

Aby nie zostać porażonym w spotkaniu z Bogiem, konieczne było wcześniejsze uświęcenie pojmowane jako oddzielenie się od grzesznego świata i stopniowe zbliżanie się do sfery sacrum. 
Naród izraelski został oddzielony od narodów pogańskich, aby być poświęconym dla Jahwe. Spośród 12 pokoleń, pokolenie Lewiego było oddzielone z przeznaczeniem dla posługi świątynnej. W tym pokoleniu jedna rodzina otrzymała specjalne poświęcenie. $\mathrm{Z}$ tej bowiem rodziny wybierano arcykapłana, który bardziej niż ktokolwiek inny był poddany wymogom oddzielenia. Obrzędy konsekracji najwyższego kapłana są szczegółowo opisane w Księdze Wyjścia (rozdział 29) i Księdze Kapłańskiej (r. 9): rytualna kąpiel, aby oczyścić się od kontaktów ze światem świeckim, namaszczenie, które nasyca świętością, szaty, które wyrażają przynależność do sfery sacrum, rozmaite ofiary rytualne. Surowe przepisy zobowiązywały później arcykapłana do podtrzymywania tego oddzielenia: nie wolno mu było nawet czynić żałoby po śmierci własnego ojca lub matki zbliżając się do ich zwłok (Kpł 21,11). Powinien unikać wszelkiego kontaktu ze śmiercią, aby być godnym Boga żywego.

W błogosławieństwie, którego udzielił Mojżesz Lewiemu, jest bardzo podkreślony aspekt zerwania relacji z ludźmi. Według tego błogosławieństwa Lewi „mówi o swym ojcu i matce: ja ich nie widziałem; nie zna już swoich braci i nie chce rozpoznać swych dzieci" (Pwt 33,9). Aby osiągnąć i utrzymać dobre relacje z Bogiem wydawało się koniecznym całkowite odseperowanie od ludzi. Taka perspektywa odpowiada znanej scenie z Księgi Wyjścia, kiedy to po uczczeniu złotego cielca Mojżesz zarządził, aby „ci, którzy są z Panem”, przeszli tam i z powrotem przez obóz i zabili „,kto swego brata, kto swego przyjaciela, swego krewnego" (Wj 32,26-27) i później konkluduje, że w ten sposób zasłużyli oni na kapłaństwo.

Podobne pojęcie uświęcenia poprzez oddzielenie rytualne odnajdujemy również, jak to już nadmieniłem, w ofiarach rytualnych. Ofiary bowiem były składane w miejscu świętym, oddzielonym od przestrzeni świeckiej i polegały na przejściu ofiary ze świata ziemskiego do sfery sacrum.

\section{Podstawowy aspekt kapłaństwa: pośrednictwo}

W tajemnicy Chrystusa nie znajduje oczywiście zastosowania pojęcie uświęcenia poprzez ryty oddzielenia. Konsekwentnie więc ten, kto tak pojmuje kapłaństwo i ofiary, powinien by stwierdzić, że Chrystus nie jest kapłanem i nie złożył ofiary. Nowy Testament jednak nie obrał tej drogi, ale dokonał wysiłku pogłębienia pojęć kapłaństwa i oczyszczenia. Zamiast pozostać na powierzchni i określić kapłaństwo za pomocą rytów i przepisów zewnętrznych, autorzy Nowego Testamentu, a szczególnie autor Listu do Hebrajczyków, dokonali refleksji na temat celowości ofiary i kapłaństwa. Uznali oni, że celem śmierci Chrystusa było osiągnięcie pośrednictwa między ludźmi a Bogiem. „Każdy bowiem arcykapłan — pisze autor Listu do Hebrajczyków — dla ludzi bywa ustanawiany w sprawach odnoszących się do Boga" (Hbr 5,1). Definicja ta znajduje zastosowanie do kapłaństwa starotestamentalnego, ponieważ kapłani składali ofiary za lud, przekazywali ludowi Boskie odpowiedzi wyznaczające sposób postępowania w trudnych sytuacjach i błogosławili lud w imię Jahwe. Należy jednak zauważyć, że kiedy myślano wówczas o kapłaństwie, funkcja pośrednictwa nie była łatwo dostrzegalna ponieważ cała uwaga zwró- 
cona była na przywilej kapłański wchodzenia w bliski kontakt z Bogiem. Najwyższy kapłan widziany był jako osobistość wyniesiona w swojej godności ponad ludzi i dopuszczona do bliskiego kontaktu z Bogiem. Kiedy Syrach opisuje kapłanów Aarona (45,6-22) czy też Szymona (50,1-21), nie kładzie nacisku na aspekt mediacji, ale na nadzwyczajną chwałę kapłaństwa. Pomimo to jednak elementem specyficznym kapłaństwa nie jest chwała tego, który jest „wywyższony" (Syr 45,6), ale uzdolnienie do pośrednictwa między Bogiem i ludźmi.

Jeżeli więc w misterium Chrystusa nie odnajdujemy żadnego z aspektów zewnętrznych kapłaństwa, to jednak aspekt pośrednictwa znajduje w nim doskonałą realizację. W swoim misterium paschalnym Chrystus wyjednał ludziom dostęp do Boga. Przeszkoda grzechu została obalona. Zostało ustanowione Nowe Przymierze. Teraz, w Chrystusie uwielbionym, wierzący mają pośrednika wiarygodnego i pełnego wyrozumiałości dila ich potrzeb ( $\mathrm{Hbr} 7,25$; 4,15-16). Należy więc podsumować, że pomimo zewnętrznych pozorów przeciwnych, śmierć Chrystusa była ofiarą miłą Bogu i że Chrystus posiada w sposób pełny godność kapłańską.

\section{Oddzielenia rytualne a dynamizm komunii}

We wnikliwej analizie ukazuje List do Hebrajczyków wszystkie braki kapłaństwa starotestamentalnego. Przed przyjściem Chrystusa braki te nie były latwo dostrzegalne. Starotestamentalny kult był jeszcze wtedy najlepszym sposobem organizacji życia liturgicznego dla ludu wybranego. Wśród innych zalet ukazywał konieczność pośrednictwa ofiarniczego. Grzeszny człowiek nie może pretendować do tego, aby stać się darem godnym Boga. Musi szukać zwierzęcia ofiarnego „,bez skazy”. Prawo Mojżeszowe nakazywało wybierać z owiec lub cielców zwierzę bez jakiegokolwiek defektu fizycznego. Takie zwierzę wydawało się być ofiarą godną przyjęcia przez Boga.

W rzeczywistości jednak - jak to zresztą wyraźnie ukazuje list — kapłaństwo, które dysponuje tylko takim rodzajem ofiar, jest niedoskonałe z samej zasady. Nie może ono dokonać mediacji, ponieważ ofiara jest czymś całkowicie zewnętrznym w stosunku do człowieka. Jakaż relacja może istnieć między martwym ciałem zwierzęcia zabitego a sumieniem osoby ludzkiej? „Niemożliwe jest bowiem - mówi list do Hebrajczyków — aby krew cielców i kozłów usuwała grzechy” (Hbr 10,4). Chodzi o „dary i ofiary, nie mogące udoskonalić w sumieniu tego, który składa ofiarę" $(9,9)$. Z drugiej zaś strony jakaż więź może istnieć między zabitym zwierzęciem a Bogiem żyjącym? Oczywiście żadna. Bóg nie żywi się mięsem cielców ani nie pije krwi kozłów - mówi Psalm 50 (49). Kult starotestamentalny nie miał więc żadnej wartości mediacyjnej.

Dlatego też w systemie uświęcania za pomocą oddzieleń rytualnych jedynym efektem faktycznie osiąganym było utrzymywanie tych oddzieleń: oddzielenia Izraela od narodów pogańskich, kapłanów od ludu (lud nie mógł wchodzić wraz z kapłanem do sanktuarium, por. Łk 1,10.21), oddzielenia między zwykłymi kapłanami a arcykapłanem (kapłani nie mogli towarzyszyć arcykapłanowi, gdy ten wchodził do Miejsca Najświętszego), oddzielenia kapłana od ofiary (kapłan nie mógł złożyć w ofierze siebie, ponieważ sam był 
grzesznikiem, a ofiara nie mogła uświęcić w sposób faktyczny kapłana — jak to widzieliśmy wyżej).

Jezus zastąpił te usiłowania mediacji za pomocą systemu rytów zewnętrznych poprzez ofiarę i kapłaństwo całkiem innego rodzaju. Zamiast uświęcenia rytualnego za pomocą oddzieleń, Jezus dokonał uświęcenia rzeczywistego poprzez solidarność między osobową. Ustanowił nowy dynamizm pojednania i komunii.

Ofiara Chrystusa, jak to już zaznaczyliśmy, nie była obrzędem rytualnym, ale wydarzeniem rzeczywistym. Jego ofiara nie była rytem zewnętrznym, ale w pełni osobistym zaangażowaniem. Chrystus „złożył Bogu samego siebie jako ofiarę" (Hbr 9,14). Nie wziął krwi kozłów i cielców, ale przelał swą własną krew (Hbr 9,12). Ofiary ze zwierząt zastąpił „ofiarą swojego ciała” (Hbr 10,10). Z tego to powodu Jego kapłaństwo jest całkiem innego rodzaju.

Nie wystarczy powiedzieć, że w przypadku Chrystusa chodzi o kapłaństwo egzystencjalne zamiast rytualnego. Trzeba też zauważyć, że opiera się ono na ofierze osobistej Chrystusa, która czyni z Niego doskonałego pośrednika, ponieważ jego ofiara wypływa z serca i polega na otwarciu całej Jego ludzkiej egzystencji na relację z Bogiem i relację z ludźmi.

Aby być dobrym pośrednikiem, trzeba mieć oczywiście dobre relacje z obydwiema stronami. Wykazałem wyżej, że ofiara ze zwierząt nie może dokonać skutecznego pośrednictwa między Bogiem a ludźmi, ponieważ zwierzę jest niezdolne do nawiązania kontaktów personalnych. Zaś osobista ofiara Chrystusa opierała się na tej podwójnej relacji i polegała na doprowadzeniu jej do najwyższego stopnia zaangażowania.

Po co właściwie Jezus wycierpiał Mękę? Ponieważ był Synem Bożym i bratem ludzi. Gdyby nie potwierdził tej swojej relacji synowskiej w stosunku do Boga, nie byłby skazany. Gdyby nie zaakceptował do końca uwarunkowania ludzkiego, nie umarłby. A w jakim właściwie celu wycierpiał Mękę? Aby doprowadzić tę podwójną relację do najwyższej doskonałości. Jezus z miłości wykonał wolę Ojca aż do śmierci. Jezus z miłości posunął aż do śmierci braterską solidarność z nami. Nie brakuje tekstów Nowego Testamentu, które wyrażają te dwa fundamentalne aspekty męki. Pięrwszy aspekt posłuszeństwa synowskiego ukazuje się nam z całą dramatyczną siłą w Getsemani. Przezwyciężając swoją ludzką trwogę Jezus mówi: „Nie moja wola, ale Twoja niech się stanie" (Łk 22,42; por. Mt 26,39; Mk 14,36). Jezus stał się „posłusznym aż do śmierci - i to śmierci krzyżowej” (Flp 2,8). Drugi aspekt miłości braterskiej, wyraża się z zadziwiającą głębią w ustanowieniu Eucharystii: „Bierzcie i jedzcie, to jest Ciało moje... Pijcie z niego wszyscy, to jest moja Krew...” (Mt 26,26-28 i paralelne). „Umiłowawszy swoich, którzy byli na świecie, do końca ich umiłował" (J 13,1).

\section{5. Śmierć i mediacja kapłańska}

Śmierć Chrystusa, będąc wydarzeniem zewnętrznie tragicznym, została całkowicie przekształcona od wewnątrz, to znaczy poprzez nie znającą granic wspaniałomyślność Serca Jezusowego. Wśród tylu zadziwiających aspektów, 
dwa wydają mi się tu najważniejsze dla naszego tematu, tzn. relacja między śmiercią i kapłaństwem z jednej strony, a połączenie tych dwóch aspektów miłości z drugiej.

Według Starego Testamentu między śmiercią a kapłaństwem nie było absolutnie żadnego związku. Kapłani winni unikać bezwzględnie jakiegokolwiek kontaktu ze śmiercią, ponieważ panowało przekonanie o diametralnym przeciwieństwie między Bogiem jako źródłem życia a zniszczeniem powodowanym przez śmierć. W samej rzeczy śmierć kapłana oznaczała koniec jego funkcji kapłańskich. Z punktu widzenia mediacji śmierć, sama przez się, jest wydarzeniem katastrofalnym, ponieważ powoduje zerwanie relacji między osobami. Po śmierci nie są już one możliwe i dlatego śmierć bliskich napawa nas tak wielkim bólem. Gdy zaś chodzi o relacje z Bogiem, to według Starego Testamentu sytuacja była jeszcze gorsza: umarli są oddzieleni od Boga, nie mogą go wychwalać, nie mogą nawet o Nim pamiętać (Ps 6,6; 88,11-13; Iz 38,18). Zaś kapłaństwo Chrystusa nie tylko że nie zostało unicestwione przez śmierć, ale w niej osiągnęło swą najwyższą doskonałość, ponieważ Serce Jezusa przezwyciężyło śmierć, odwracając całkowicie jej sens i skutki. Z wydarzenia niszczącego miłość Chrystusa uczyniła ją wydarzeniem ustanawiającym Przymierze. Zamiast zniszczenia relacji Jezusa z Bogiem i z nami, Jego śmierć wzmocniła te relacje i spowodowała, że stały się od tego momentu niezniszczalne. Relacja z Bogiem została doprowadzona do doskonałości przez ofiarę synowskiego posłuszeństwa aż do śmierci. Relacja z nami stała się doskonałą i definitywną przez dar z samego siebie aż do śmierci. Trzeba zauważyć, że okoliczności zewnętrzne były całkowicie niesprzyjające takiej orientacji. Jezus faktycznie znajdował się w sytuacji opuszczenia ze strony Boga, który nie zainterweniował, aby go wybawić od niesłusznej kary i, z drugiej strony, musiał znosić pełne nienawiści traktowanie przez ludzi: zdradę, zaparcie, rażącą niewdzięczność, śmiertelną wrogość, haniebną śmierć. Wszystkie te okoliczności, które zasługiwały na reakcję odpowiadającą odrzuceniu, zostały przekształcone w tych samych okolicznościach na zwycięstwo miłości. „Gdzie jednak wzmógł się grzech, tam jeszcze obficiej rozlała się łaska" (Rz 5,20), tzn. miłość wspaniałomyślna, darmowa. Kapłaństwo Chrystusa charakteryzuje się odtąd tym aktem pośrednictwa egzystencjalnego i osobistego, wyplywającego z Jego Serca.

Aby uzupełnić naszą perspektywę, zauważmy jeszcze drugi aspekt, tzn. ścisłe powiązanie ze sobą dwóch wymiarów miłości: miłości Boga i miłości do braci. Jezus słowami nauczał o tej jedności; jest to specyficzne posłannictwo Ewangelii. Zrealizował tę jedność swymi czynami i śmiercią. Kapłaństwo starotestamentalne nie uważało za możliwe podtrzymywanie równoczesne tych dwóch wymiarów miłości. Aby być blisko Boga trzeba było zwalczać Jego wrogów i dlatego Lewici nie tylko odłączyli się od swych braci grzeszników, ale ich pozabijali (Wj 32,26-29). Trzeba było wybierać między Bogiem a ludźmi. Jezus zaś zaakceptował ten dylemat. Nie uważał, aby wierność wobec Boga miała Go prowadzić do potępienia ludzi. Wprost przeciwnie, zrozumiał, że posłuszeństwo względem Boga wymagało zbawienia grzeszników, ponieważ Bóg pragnie tryumfu miłosierdzia, a nie ofiary rytualnej. W Sercu Jezusa więc te 
dwa wymiary miłości umocniły się nawzajem. Synowskie posłuszeństwo pobudzało Jego braterską miłość w stosunku do ludzi, a miłosierdzie względem ludzi utwierdzało Go w posłuszeństwie synowskim względem Boga. Aby odpowiedzieć na miłość Ojca, Jezus oddał się braciom. Aby zbawić braci, Jezus wprowadził ich w swoją bliską relację z Ojcem. Śmierć Jezusa spoiła ze sobą definitywnie te dwa wymiary miłości, które odpowiadają dwom wymiarom krzyża: pionowemu i poziomemu. Kapłaństwo Chrystusa cechuje się więc odtąd nierozłączną jednością tych dwóch wymiarów.

Wynika z tego, że wszystkie oddzielenia Starego Testamentu zostały unicestwione. W ofierze Chrystusa nie istnieje już żadna z separacji rytualnych. Śmierć Chrystusa dlatego właśnie stała się ofiarą miłą Bogu, ponieważ przez nią Jezus zniósł wszelkie przedziały. Ofiara była miła Bogu, ponieważ nie była darem zewnętrznym w stosunku do kapłana, ale był nią sam kapłan, który składał w ofierze nie jakiś ryt zewnętrzny, ale własną egzystencję. Ta osobista ofiara kapłana była również miłą dla Boga, ponieważ polegała na akcie doskonałej solidarności z braćmi — grzesznikami. A więc zamiast separacji między kultem a życiem, między ludem a kapłanem, między kapłanem a darem ofiarnym, które powodowały również separację między ofiarą a Bogiem, znajdujemy w śmierci Jezusa doskonałe połączenie między kultem a egzystencją rzeczywistą, doskonałą łączność kapłana-ofiary z Bogiem i ludem, a w końcu otwarcie tej komunii także i na pogan. W miejsce uświęcenia szukanego na drodze separacji Chrystus proponuje nam uświęcenie otrzymane przez przyjęcie innych ludzi. Jego kapłaństwo uruchamia potężny dynamizm pojednania i komunii.

\section{KAPŁAŃSTWO LUDU BOŻEGO}

Zniesienie oddzieleń rytualnych sprawia, że kapłaństwo nie jest przywilejem zarezerwowanym tylko dla nielicznych, ale jest godnością przekazaną wszystkim wierzącym. Kapłaństwo Chrystusa jest fundamentem kapłaństwa ludu Bożego.

\section{Obietnica i aktualizacja kapłaństwa ludu Bożego}

Perspektywa została otwarta w słynnym tekście Księgi Wyjścia. Kiedy Izraelici przybyli na pustynię Synaj, Jahwe uczynił następującą obietnicę: „Teraz jeśli pilnie słuchać będziecie głosu mego i strzec mojego przymierza... będziecie Mi królestwem kapłanów i ludem świętym” (Wj 19,5-6). Chodziło o obietnicę uwarunkowaną (, jeśli pilnie słuchać będziecie...”). Cała sukcesywna historia, począwszy od wydarzenia ze złotym cielcem, wykazała dobitnie, że ten warunek nigdy nie został spełniony. Izrael zawsze odmawiał posłuszeństwa Bożemu głosowi. Konstatuje to ze smutkiem Jeremiasz: „To jest naród, który nie slucha głosu Jahwe, swego Boga" (Jr 7,28; por. 7,21-27).

To co w Starym Testamencie było obietnicą nie do zrealizowania, stało się faktem dzięki ofierze Chrystusa. Mówi o tym wyraźnie Apokalipsa. Sami chrześcijanie stwierdzają tam w mowie pochwalnej skierowanej do Chrystusa: 
„Temu, który nas miłuje i który przez swą krew uwolnił nas od naszych grzechów i uczynił nas królestwem — kapłanami dla Boga i Ojca swojego, Jemu chwała i moc na wieki wieków. Amen" (Ap 1,5-6). Fragment paralelny precyzuje, że uczestnictwo w kapłaństwie nie ogranicza się już do jednego pokolenia ani nawet do całego ludu wybranego, ale jest rozciągnięte na ludzi „z każdego pokolenia, języka, ludu i narodu" (Ap 5,9). Te dwa fragmenty pokazują, że kapłaństwo ludu Bożego stało się faktem dzięki Chrystusowi (... „i uczynił nas... kapłanami” - 1,6), przez Jego gwałtowną śmierć (Baranek został „,zabity” - 5,9 i „nabył” - egorasas - Bogu” cały ten lud). Użyte tu wyrażenia nie są terminami rytualnymi lecz egzystencjalnymi.

Taka sama relacja $z$ dramatycznym wydarzeniem na Kalwarii jest podkreślona w innym tekście Nowego Testamentu, który proklamuje godność kapłańską całego ludu chrześcijańskiego. Chodzi o wspaniały fragment 1 Listu św. Piotra, który używa różnorakich terminów. Aby zrobić aluzję do męki i uwielbienia Chrystusa, św. Piotr czerpie inspirację z Ps 117,22 (LXX) i porównuje Chrystusa do kamienia odrzuconego przez budowniczych, ale wybranego przez samego Boga. Św. Piotr zachęca wierzących, ,aby zbliżyli się do Chrystusa - żywego kamienia" i mówi, że wtedy staną się również i oni sami kamieniami żywymi i zostaną użyci do budowy „duchowego domu”, aby stanowić „święte kapłaństwo”, które polega na „składaniu duchowych ofiar przyjemnych Bogu przez Jezusa Chrystusa” $(1$ P 2,4-5). Później odnosi Apostoł do ludu chrześcijańskiego wszystkie najbardziej chwalebne tytuły, które były kiedyś nadane czy obiecane Izraelowi: „Wy zaś jesteście wybranym plemieniem, królewskim kapłaństwem, narodem świętym, ludem przeznaczonym do zbawienia, abyście ogłaszali dzieła potęgi Tego, który was wezwał z ciemności do swojego przedziwnego światła" (1 P 2,9).

Mówiąc o „kapłaństwie” używa św. Piotr terminu ukutego przez Septuagintę dla przetłumaczenia $\mathrm{Wj} 19,6$. Nie jest to termin abstrakcyjny wyrażający godność osób, ale termin konkretny, który określa grupę osób albo działalność kolegialną i który możemy przetłumaczyć jako „organizm kapłański”. Wybór tego terminu jest wymowny. Już dawno temu egzegeta luterański J.H. Elliott zauważył z podziwu godną uczciwością, że termin ten nie dopuszcza przyjęcia pozycji Lutra przyznającej kapłaństwo każdemu pojedynczemu chrześcijaninowi w perspektywie indywidualistycznej (J.H. Elliott, The Elect and the Holy, Leiden 1966, s. 223). Sw. Piotr widzi zaś kapłaństwo w perspektywie łączności i komunii. Kapłaństwo jest przyznane przez niego całemu ludowi Bożemu, wiernym świeckim i pasterzom, w ich wspólnej łączności wiary i życia z osobą i tajemnicą Chrystusa. Wszyscy razem tworzą „organizm kapłański”, tak jak wszyscy razem, choć w różnych funkcjach, wchodzą w konstrukcję „duchowego domu”. Jeżeli głównym aspektem kapłaństwa Chrystusowego jest rozpoczęcie i pogłębianie dynamizmu komunii, to fundamentalnym aspektem kapłaństwa ludu Bożego będzie również przyjęcie i poszerzanie więzów tej komunii.

Choć nie nazywa chrześcijan wprost „kapłanami”, to jednak List do Hebrajczyków zawiera również potwierdzenie kapłaństwa wszystkich wierzących. Rzeczywiście jego autor deklaruje, że Chrystus ,jedną ofiarą udoskona- 
lił na wieki tych, którzy są uświęcani” (Hbr 10,14). Tłumaczenia nie oddają dobrze całej doniosłości greckiego sformułowania i nie pozwalają dostrzec aspektu kapłańskiego w użytym czasowniku teleioun. Słowo to, którego podstawowym znaczeniem jest „udoskonalać”, zostało użyte przez Septuagintę dla określenia konsekracji kapłańskiej. Nie ma ono innych zastosowań w Pięcioksięgu greckim, W Liście do Hebrajczyków czasownik ten jest użyty 3 razy w odniesieniu do Chrystusa i określa właśnie Jego konsekrację kapłańską która, jak wiemy, nie była rytualną, lecz rzeczywistą, ponieważ dokonała się poprzez cierpienia (Hbr 2,10) i posłuszeństwo krzyża (Hbr 5,8-9).

A więc po kilkakrotnym stwierdzeniu, że Chrystus został „udoskonalony”, tzn. „konsekrowany na kapłana” (Hbr 2,10; 5,9; 7,28), autor oświadcza, że poprzez tę samą jedyną ofiarę Chrystus „udoskonalił”, to znaczy „konsekrował na kapłanów" wszystkich wierzących. Zauważamy tu nowy kontrast w stosunku do kapłaństwa starotestamentalnego. W tamtym kapłaństwie konsekracja odnosiła się wyłącznie do pojedynczej osoby, która otrzymując ją zostawała oddzielona od innych. Zaś w przypadku Chrystusa otrzymana konsekracja jest przekazywana innym i staje się elementem łączności. Wytłumaczenie tej nowości polega na fakcie, że konsekracja Chrystusa nie dokonała się poprzez ryt odłączenia, lecz przez akt solidarności i daru z siebie. Oparte na duchowym dynamiźmie pojednania i komunii kapłaństwo Chrystusowe jest więc przekazywane całemu ludowi.

2. W jaki sposób jest sprawowane kapłaństwo ludu Bożego?

Jak więc powinno być sprawowane kapłaństwo ludu Bożego? Na to pytanie odpowiada się często w sposób niezadowalający. Znowu zwycięża tendencja odniesienia do modelu starotestamentalnego i myślenia o rytualnym sprawowaniu kapłaństwa. Wielu myśli, że wierni sprawują swoje kapłaństwo uczestnicząc aktywnie w obrzędach chrześcijańskich. W rzeczywistości umieszczenie na pierwszym planie ceremonii nie jest zgodne $\mathrm{z}$ autentyczną perspektywą kapłaństwa chrześcijańskiego. Jeżeli kapłaństwo ludu Bożego jest uczestnictwem w kapłaństwie Chrystusowym, to logicznie rzecz biorąc powinno być sprawowane w ten sam sposób. Widzieliśmy, że kapłaństwo Chrystusa nie było rytualne, lecz egzystencjalne, nie zewnętrzne ale osobiste, nie dokonało się poza konkretną ludzką egzystencją, ale w niej samej poprzez dwie dyspozycje osobiste ściśle ze sobą złączone: synowskiego posłuszeństwa względem Boga i braterskiej solidarności z ludźmi. Wynika stąd, że kapłaństwo ludu Bożego powinno realizować się również na tych dwóch drogach.

Sw. Piotr oświadcza, że sprawowanie kapłaństwa wiernych polega na "składaniu duchowych ofiar, przyjemnych Bogu przez Jezusa Chrystusa" $(2,5)$. Nie precyzuje, na czym polegają te „duchowe ofiary”. Kontekst jednak pozwala sobie wyrobić pojęcie w tym względzie. Nie chodzi tu o kult pojęty abstrakcyjnie, umysłowo, jak to czasem tłumaczono. Ofiary „duchowe” przeciwstawiają się ofiarom „materialnym” kultu starotestamentalnego (zabijanie nierozumnych zwierząt) i określają ofiarę osobistą chrześcijan posłusznych Duchowi Swiętemu w całym postępowaniu życiowym. Św. Piotr już na samym 
początku listu robi aluzję do ,uświęcenia”, które pochodzi od Ducha Świętego (1 P 1,2) i później napomina chrześcijan, aby ,stali się świętymi w całym swym postępowaniu" $(1,15)$. W późniejszym kontekście św. Piotr podkreśla w szczególny sposób chrześcijańskie powołanie, aby iść śladami cierpiącego Chrystusa $(2,21)$, tzn. czynić dobro również i wtedy, kiedy są źle przez innych traktowani $(2,20)$. „Taka jest bowiem łaska u Boga" $(2,20)$; to jest więc też „ofiara duchowa przyjemna Bogu" $(2,5)$.

W Liście do Rzymian św. Paweł mówi podobnie o chrześcijańskich ofiarach w ważnym fragmencie, który rozpoczyna całą sekcję parenetyczną listu: „A zatem proszę was, bracia, przez miłosierdzie Boże, abyście dali ciała swoje na ofiarę żywą, świętą, Bogu przyjemną, jako wyraz waszej rozumnej służby Bożej $(\mathrm{Rz} 12,1)$. Paweł nieczęsto używa słownictwa ofiarniczego czy kapłańskiego. Używa go tutaj i to nie na określenie ceremonii chrześcijańskich, ale życia chrześcijańskiego przedstawionego jako ofiara osobista, dokonana w życiu konkretnym. Zamiast składać Bogu ciała zabitych zwierząt, chrześcijanie powinni przedstawić Bogu ofiarę żywą i osobistą: własne ciało.

Kolejne zdania listu precyzują sens tej ofiary własnego ciała, na której polega sprawowanie kapłaństwa. Precyzują go w dwóch kierunkach, które odpowiadają również dwom wymiarom ofiary Chrystusa, tzn. posłuszeństwa synowskiego i braterskiej solidarności. Paweł rzeczywiście kontynuuje napomnieniem, aby szukać „woli Bożej”, „tego, co jest dobre, co Bogu przyjemne i co doskonałe" $(12,2)$. Następnie wyjaśnia chrześcijanom, że my, choć jesteśmy liczni, „tworzymy jedno ciało w Chrystusie, a każdy z osobna jesteśmy nawzajem dla siebie członkami” $(12,5)$ i powinniśmy w konsekwencji „zaradzać potrzebom braci" $(12,13)$, a nawet szukać dobra w odnoszeniu się do wszystkich ludzi $(12,14)$. Posłuszeństwo względem Boga i solidarność międzyludzka stanowią więc dwa istotne składniki kultu chrześcijańskiego.

List do Hebrajczyków reprezentuje podobne rozumowanie. Po zdefiniowaniu ofiary Chrystusa jako posłuszeństwa (Hbr 5,8$)$ i osobistego przylgnięcia do woli Bożej (10,5-9) autor listu zachęca wierzących do ,pełnienia woli Bożej" $(10,36 ; 13,21)$ pomimo doświadczeń życiowych. Z drugiej zaś strony, po wykazaniu, że ofiara Chrystusa była najwyższym przejawem solidarności z braćmi aż do „upodobnienia się do nich we wszystkim” i doświadczenia ich cierpień $(2,17-18 ; 4,15-16 ; 5,7-8)$, autor oświadcza, że ofiary składane przez chrześcijan powinny również polegać na życiu pełnym miłości: „Nie zapominajcie - mówi - o dobroczynności i wzajemnej więzi (koinonia), gdyż cieszy się Bóg takimi ofiarami” $(13,16)$. W wersetach poprzedzających autor polemizował ze starotestamentalną koncepcją kultu, która kładła nacisk na zachowanie przepisów zewnętrznych. Chrześcijanin nie może pojmować religii jako systemu praktyk zewnętrznych, które są dołączone do życia. Kapłaństwo chrześcijan winno być sprawowane właśnie w konkretnym życiu. Idąc za przykładem Chrystusa, który przemienił swą mękę i śmierć w doskonały dar synowskiego posłuszeństwa i braterskiej solidarności, chrześcijanie sprawują swe kapłaństwo przemieniając wszystkie okoliczności własnego życia tak, aby umacniać komunię z Bogiem i braćmi. 


\section{Konieczność Chrystusowego pośrednictwa}

Z tego, co dotychczas przedstawiłem, można by odnieść wrażenie całkowitej sekularyzacji kapłaństwa ludu Bożego, sprawowanego w najróżniejszych okolicznościach świata doczesnego. Mógłbym na to odpowiedzieć, że wprost przeciwnie, kładłem nacisk na uświęcanie całej chrześcijańskiej egzystencji podkreślając autentyzm tego uświęcenia, które ma być nie tylko zewnętrzną powłoką, ale akceptować dogłębne działanie Ducha Świętego we wszystkich dziedzinach życia.

Muszę jednak przyznać, że przedstawiony tu obraz wymaga uzupełnienia przez dodanie jeszcze dwóch nieodzownych elementów. Kapłaństwo ludu Bożego nie może się obejść bez modlitwy i bez sakramentów. Byłoby to zgubnym w skutkach zludzeniem, gdybyśmy wyobrażali sobie, że samemu można przekształcić wlasne życie na coraz doskonalsze narzędzie zjednoczenia z Bogiem i ludźmi.

Sam Chrystus musiał odwoływać się do modlitwy, aby móc dokonać swej ofiary egzystencjalnej. Co więcej, jego ofiara polegała w pierwszym rzędzie na modlitwie. Stwierdza to wyraźnie List do Hebrajczyków. Po przypomnieniu, że „każdy arcykapłan jest ustanawiany, aby składał dary i ofiary” (Hbr 5,1), autor stwierdza, że Chrystus ,z głośnym wołaniem i płaczem za dni ciała swego ofiarował (prosenegkas) gorące prośby i błagania Temu, który mógł Go wybawić od śmierci i został wysłuchany" $(5,7)$. Poprzez intensywną modlitwę otworzył Jezus całe swoje ludzkie bytowanie na przemieniającą siłę Boskiego Ducha. Jedynie w ten sposób mógł przezwyciężyć wszystkie siły zła, które się przeciw Niemu sprzysięgły i zatryumfować nad nimi dynamizmem Bożej komunii. Tym bardziej lud Boży potrzebuje wytrwałej modlitwy, aby sprawować swe kapłaństwo w świecie wielkich sprzeciwów hamujących postęp tej komunii.

Krótko mówiąc, lud Boży musi zrozumieć, że jego kapłaństwo nie może istnieć bez Chrystusa. Rzeczywiście, jest ono kapłaństwem uczestnictwa, które całkowicie zależy od jedynego, w pełni samoistnego kapłaństwa, tzn. kapłaństwa Chrystusowego. Kapłaństwo ludu Bożego może istnieć tylko w stałym powiązaniu z kapłaństwem Chrystusa. Nie może być praktykowane, jak tylko przez Chrystusa, z Chrystusem i w Chrystusie. Jedynie Chrystus jest „pośrednikiem między Bogiem a ludźmi” (1 Tm 2,5). I dlatego wszystkie teksty Nowego Testamentu, które mówią o kapłaństwie ludu, kładą nacisk na niezbędną mediację Chrystusa. Wszyscy wierzący zachęcani są do łączności z Bogiem, ale „przez krew Jezusa” (Hbr 10,19). Wszyscy też są wezwani, aby uczynić wolę Bożą, lecz ,przez Jezusa Chrystusa” (Hbr 13,21). Wszyscy mogą składać swe „duchowe ofiary”, lecz zawsze „przez Jezusa Chrystusa” (1 P 2,5).

Przyjęcie pośrednictwa Chrystusowego stanowi podstawowy aspekt kapłaństwa ludu Bożego. W tej perspektywie jawi się nam konieczność sakramentów i sakramentalnego kapłaństwa jako warunku do sprawowania kapłaństwa powszechnego. Trzeba więc dobrze zrozumieć naturę i funkcję sakramentów. W przeciwnym wypadku istnieje wielkie ryzyko powrotu do starotestamentalnej koncepcji kultu rytualnego. 
Pomiędzy kultem sakramentalnym chrześcijańskim a kultem rytualnym Starego Testamentu można zauważyć pewne podobieństwa: jeden i drugi zawierają faktycznie obrzędy religijne. Obok tego podobieństwa istnieje jednak głęboka różnica. W kulcie starotestamentalnym ryty te nie miały relacji z doskonałym darem egzystencjalnym z tej choćby prostej racji, że taka ofiara jeszcze nie istniała. Uważano, że kult posiada wartość sam w sobie. W rzeczywistości jednak, jak to już widzieliśmy, nie był on w stanie dokonać skutecznego pośrednictwa, ponieważ właśnie brakowało mu doskonałej ofiary egzystencjalnej.

Sakramenty chrześcijańskie zaś, przeciwnie, są w ścisłej relacji z doskonałą ofiarą egzystencjalną Chrystusa. Ich funkcją jest jedynie uobecnianie tej ofiary egzystencjalnej z całym jej dynamizmem uświęcenia i komunii tak, aby ten dynamizm był przekazywany do ezgystencji wiernych.

Sakramenty więc nie są, jak w starotestamentalnych rytach, kultem odseparowanym od realnego życia. Co więcej, mają podwójne powiązanie z życiem. Z jednej strony uobecniają życie Chrystusa; z drugiej zaś - zostały ustanowione, aby oddziaływać na życie wierzących. W ten sposób'są znakami i narzędziami mediacyjnego aktu Chrystusa, jego ofiary płynącej'z miłości. Uczestnictwo w sakramentach jest więc aspektem nieodzownym kapłaństwa ludu Bożego, ale nie stanowi jego najważniejszej czynności. Najistotniejszą funkcją kapłańską ludu Bożego jest przemienianie samego życia w ofiarę dla Boga i dar dla braci, aby zrealizować komunię ze wszystkimi. Modlitwa i uczestnictwo w sakramentach są zaś koniecznymi środkami, aby osiągnąć ten cel.

\section{Konkluzja}

Aby lepiej zdefiniować kapłaństwo ludu Bożego w jego relacji do kapłaństwa Chrystusowego, pożytecznym byłoby rozważyć jeszcze inne dodatkowe aspekty. W ramach jednego wykładu nie można jednak powiedzieć wszystkiego. Jestem świadom tego, że uprościłem i przedstawiłem schematycznie cały problem po to, aby był przez to bardziej przejrzysty. Uważałem za rzecz bardzo ważną podkreślić oryginalność kapłaństwa Chrystusowego, a w konsekwencji i kapłaństwa ludu Bożego. Ponieważ prezbiterat jest na usługach jednego i drugiego, kapłani wyświęceni powinni koniecznie wyrobić sobie właściwe pojęcie o kapłaństwie po to, aby móc dobrze rozumieć swe własne posłannictwo i realizować je w sposób owocny.

Na pierwszy rzut oka krzyż Chrystusa oznaczał koniec kapłaństwa starotestamentalnego. W rzeczywistości jednak doprowadził go do pełni, ponieważ Chrystus nie przyszedł po to, aby znieść, ale wypełnić Prawo (Mt 5,17). Kult nie ogranicza się już do rytów zewnętrznych oddzielonych od życia, ale polega na przemienianiu świata przez miłość, która pochodzi od Boga. To właśnie Serce Chrystusa dokonało tej przemiany w okolicznościach najmniej temu sprzyjających. To z Serca Chrystusowego, poprzez sakramenty, które uobecniają jego najwyższy dar, lud Boży otrzymuje siłę miłości, która uzdalnia go do kontynuacji tej przemiany świata. Taka jest podstawowa funkcja jego ka- 
płaństwa. Natomiast kapłaństwo sakramentalne jest na usługach tego nowego kapłaństwa. Jego zadaniem jest bycie sakramentem mediacji Chrystusowej i przekazywanie wszystkim dynamizmu pojednania i komunii, która wypływa z ofiary Chrystusa.

Rzym KS. ALBERT VANHOYE SJ

ttumaczyt: Ks. Stanistaw Hatas SCJ

* Autor artykułu ks. Albert VANHOYE SJ jest profesorem egzegezy Nowego Testamentu na Papieskim Instytucie Biblijnym w Rzymie („Biblicum”), a ostatnio, w latach 1984-90, pełnił funkcję Rèktora tej uczelni. Jest również członkiem Papieskiej Komisji Biblijnej.

Ks. prof. Vanhoye jest światowej sławy specjalistą w zakresie problematyki Listu do Hebrajczyków. Wypracował on metodę badań struktury literackiej, która jest nazywana jego nazwiskiem. Jego najważniejsze publikacje naukowe to:

- La structure littéraire de l'épître aux Hébreux (Paris 1976²),

- Situation du Christ, Hébreux 1-2 (Paris 1969), oraz

- Prêtres anciens, prêtre nouveau selon le Nouveau Testament, Paris 1980 (która doczekała się już tłumaczenia na j. włoski, hiszpański i angielski).

Ks. Vanhoye przebywał w Polsce w dniach od 29 września do 9 października 1990 r. Niniejszy artykuł jest autoryzowanym tekstem wykładu wygłoszonego na Papieskiej Akademii Teologicznej dnia 5 października $1990 \mathrm{r}$.

\section{O. Gabriel Witaszek CSsR}

\section{AMOS Z TEKOA, PROROK PRZYSZŁOŚCI}

\section{MIESZKANIEC JUDEI}

Z tytułu księgi dowiadujemy się o miejscu pochodzenia Amosa $(1,1)$; tekst stwierdza, że Amos: „(...) był jednym spośród pasterzy z Tekoa (...)”. Takie sformułowanie jawi się nieco dwuznacznie. W rzeczywistości przyimek min użyty w tekście hebrajskim, w wierszu 1,1 wskazuje na miejsce pochodzenia proroka. Z drugiej strony może odnosić się do pasterzy, podkreślając, że w tej miejscowości istniała grupa pasterzy szczególnie znanych lub do samego Amosa jako mieszkającego wśród pasterzy Tekoa ${ }^{1}$. Dwuznaczność tego przyimka pozwala na stwierdzenie, że Amos był pasterzem pochodzącym z Tekoa.

Aluzja do ojczyzny Amosa przedstawiona w księdze jest nieco dziwna jak na oryginalny tytuł księgi. W związku z czym liczni autorzy, poczynając od Buddego, utrzymywali, iż wyrażenie „był jednym spośród pasterzy z Tekoa”

1 Jou on P., Grammaire de l'Hébreu Biblique, Rome 1965, 406. 